\title{
TINJAUAN YURIDIS SENGKETA BERKEPANJANGAN DALAM PANDANGAN ANTROPOLOGI HUKUM
}

\author{
YOGA MUSADI \\ yogamusadi@gmail.com \\ 211003600292 \\ UNIVERSITAS EKASAKTI PADANG
}

1. Pendahuluan

Pemahaman "unifikasi hukum" sudah dijalankan cukup lama di NKRI. Berbagai peraturan perundangan kemudian dibuat sesuai dengan konsepsi di atas. Tujuan unifikasi peraturan perundangan tersebut adalah agar terjadi pelaksanaan hukum yang terkoordinasi, lebih tertib dan kinerjanya diharapkan meningkat (Sunaryati Hartono, 1993; 9). Lalu, pertanyaannya apakah kenyataannya demikian? Perdebatan untuk jawaban itupun setidaknya bisa terpilah dua, yang satu berkenaan dengan susunan yuridis normatifnya, satunya lagi mengenai efektivitas peraturannya di lapangan. Namun, ratarata di antara kita akan menyatakan bahwa kondisi dan kinerja hasil unifikasi hukum belum juga mengalami perbaikan signifikan. Pada saat yang sama, bahkan telah berlangsung jauh lebih lama terdapat pelbagai sistem hukum dari masyarakat dan kebudayaan-kebudayaan lain (the other cultures) selain state law (hukum negara). Masyarakatnya mempertahankan sistemsistem hukum tersebut secara dinamis sesuai dengan laju 
kebudayaannya. Sebagian pihak menganggap the other laws bagian dari masa lalu, namun sebagian lagi menyatakan bahwa mereka tetap eksis hingga kini. Dan, sebagian lainnya menyatakan ada, namun semakin terkikis (Parsudi Suparlan, 1980; 20-23). Karena konsep 'unifikasi hukum' tetap didahulukan, maka keberadaan the other laws (hukumhukum masyarakat lokal) menjadi terkendala. Kendalanya adalah: a) dari sisi masyarakat pemilik hukum lokal, mereka semakin tidak leluasa dalam mengimplementasikan hukumnya, b) dari sisi state, hukumhukum lain ditanggapi sebagai ganjalan yang dapat menghambat proses pembangunan (semesta) (Roger M. Keesing, 1992; 294). Benturan antara state law versus the other laws kemudian terjadi, dan dinamikanya terkadang tinggi, dan rendah. Konsep inilah yang dalam kajian antropologi hukum dikenal sebagai -konsep- terjadinya benturan antara legal centralism (pemusatan hukum) dengan legal pluralism (kemajemukan hukum).

2. Pembahasan

Sengketa merupakan suatu masalah sosial yang bersifat universal, Karena itu, konflik tidak perlu dilihat sebagai gejala patologis yang bersumber dari tingkah-laku abnormal, atau indikasi dari suatu kekacauan dalam dinamika kehidupan masyarakat, karena setiap komunitas masyarakat mempunyai kapasitas untuk menciptakan normanorma dan mekanisme-mekanisme tersendiri untuk menyelesaikan sengketa yang muncul dalam pergaulan sosial warga masyarakat (Nader, 1968; Coser, 1968; Roberts, 1979, Moore, 1978). Dari perspektif 
antropologi hukum, fenomena sengketa mempunyai makna ganda, yaitu : di satu sisi sengketa mempunyai makna menimbulkan perpecahan atau disintegrasi suatu kehidupan sosial, melemahkan kohesi sosial, atau menimbulkan kerusakan suatu sistem hubungan sosial dalam masyarakat. Tetapi, di sisi lain sengketa juga memiliki makna positif dalam mempertahankan integrasi sosial, memperkokoh ikatan sosial, dan memberi kontribusi untuk mengembalikan keseimbangan hubungan sosial antar individu atau kelompok dalam masyarakat. Yang disebutkan terakhir akan dapat terwujud apabila pihakpihak yang bersengketa secara bersama-sama dapat mengelola, mengendalikan, dan menyelesaikan sengketa yang dihadapi secara dewasa, bijak, dan damai, dengan atau tanpa mengundang kehadiran pihak ketiga (Gluckman, 1956). Dengan kata lain, dari perspektif antropologi hukum dikatakan sengketa tidak selalu bermakna negatif dalam kehidupan masyarakat, karena sengketa juga mempunyai makna positif yang dapat memperkokoh integrasi dan kohesi hubungan sosial dalam masyarakat, atau mengembalikan keseimbangan hubungan dan sendi-sendi kehidupan sosial. Jadi, sesungguhnya sengketa yang terjadi dalam masyarakat mengandung arti yang konstruktif dan bersifat integratif, karena sengketa juga mempunyai kekuatan tersendiri untuk membentuk, mengembangkan, menertibkan ulang suatu relasi sosial, interaksi, atau tatanan kehidupan yang sudah ada dalam masyarakat (Roberts, 1978). Secara umum dikatakan bahwa terjadinya sengketa dalam masyarakat bersumber dari persoalanpersoalan seperti berikut: 
1. Penguasaan, pemanfaatan dan distribusi sumber daya alam yang menjadipendukung kehidupan manusia (natural resource control and distribution);

2. Ekspansi batas wilayah kehidupan suatu kelompok

3. Kegiatan ekonomi masyarakat (economic activities); dan

4. Kepadatan penduduk

5. Hukum dan kebijakan pemerintah

6. Politik

7. Kemiskinan

Dari perspektif antropologi hukum, sengketa yang terjadi dalam masyarakat paling tidak dapat dikategorisasi menjadi 3 (tiga) macam, yaitu (a) Konflik kepentingan (conflict of interests); (b) Konflik nilainilai (conflict of values); dan (c) Konflik normanorma (conflict of norms). Dalam hubungan ini, Nader dan Todd (1978) menyatakan bahwa pada dasarnya sengketa yang terjadi dalam masyarakat melalui tahapantahapan (stages of conflict) seperti berikut :

1. Pada tahap pertama, sengketa berawal dari munculnya keluhankeluhan (grievance) dari salah satu pihak terhadap pihak yang lain (individu atau kelompok), karena pihak yang mengeluh merasa hakhaknya dilanggar, diperlakukan secara tidak wajar, kasar, dipersilahkan, diinjak harga dirinya, dirusak nama baiknya, dilukai hatinya, dll. Kondisi awal seperti ini disebut sebagai tahapan prakonflik (pro-conflict stage) yang cenderung mengarah kepada konfrontasi yang bersifat monadik (monadic). 
2. Pada tahap kedua, apabila kemudian pihak yang lain menunjukkanreaksi negatif berupa sikap yang bermusuhan atas munculnya keluhankeluhan dari pihak yang pertama, maka kondisi ini meningkat eskalasinya menjadi situasi konflik (conflict stage), sehingga konfrontasi antar pihak-pihak berlangsung secara diadik (diadic).

3. Pada tahap ketiga, apabila kemudian konflik antar pihakpihaktersebut ditunjukkan dan bawa ke arena publik (masyarakat), dan kemudian diproses menjadi kasus perselisihan dalam institusi penyelesaian sengketa tertentu dengan melibatkan pihak ketiga, maka situasinya telah meningkat menjadi sengketa (dispute stage), dan sifat konfrontasi antar pihak-pihak yang berselisih menjadi triadik (triadic).

Penyelesaian dalam sengketa Antropolgi Hukum.

Setiap bentuk masyarakat di mana pun dan kapan pun pada dasarnya mempunyai kemampuan untuk menciptakan normanorma dan mekanisme-mekanisme serta membangun institusi-institusi tertentu untuk menyelesaikan setiap sengketa yang muncul dalam masyarakat (Moore, 1978). Masyarakat memberi makna sengketa sebagai bagian dari dinamika kehidupan sosial, dan makna sengketa yang diberikan masyarakat juga sangat tergantung pada nilai-nilai, kepercayaan, dan norma-norma yang dianut, serta bentuk-bentuk institusi sosial yang dibangun untuk menyelesaikan sengketa (Roberts, 1978). Sistem nilai, norma, politik, ekonomi, dan keyakinan sangat mempengaruhi pilihan bentuk institusi dan model-model penyelesaian sengketa dalam 
masyarakat. Institusi penyelesaian sengketa yang dikenal dalam masyarakat paling tidak ada 2 (dua) macam, yaitu:

1. Institusi penyelesaian sengketa yang bersifat tradisional, yangbersumber dari sistem politik dan hukum rakyat dan berlangsung secara tradisional (folk institutions);

2. Institusi penyelesaian sengketa yang dibangun dan sistem politik danhukum negara (state institutions). Dalam kondisi masyarakat yang masih sederhana dan subsisten, di mana relasi antar individu, hubungan kekerabatan dan kelompok masih kuat, maka pilihan institusi untuk menyelesaikan sengketa diarahkan kepada institusi-institusi penyelesaian sengketa yang bersifat kerakyatan (folk institutions), karena institusi penyelesaian sengketa yang bersifat tradisional bermakna sebagai institusi penjaga keteraturan sosial (social order) dan dimaksudkan untuk pengembalian keseimbangan magis dalam masyarakat. Karena itu, makna penyelesaian sengketa melalui institusi tradisional dengan mengacu pada hukum rakyat (folk law) lebih ditujukan untuk mengembalikan hubungan sosial yang terganggu dan lebih dari itu mengembalikan keseimbangan magis dalam masyarakat (win-win solution). Sedangkan, sengketa yang terjadi dalam masyarakat yang kompleks dan modern, di mana relasi sosial lebih bersifat individualistik, berorientasi pada perekonomian pasar, cenderung diselesaikan melalui institusi penyelesaian sengketa yang formal dengan mengacu pada hukum negara (state institution) yang bercirikan legalistik. Institusi peyelesaian sengketa yang mengacu pada hukum negara dikenal sebagai pengadilan (court institution), yang digerakkan oleh hakim- 
hakim pengadilan (judges), dengan menerima, memeriksa dan memutuskan suatu sengketa untuk menyatakan pihak yang satu menang dan pihak yang lain kalah dalam sengketa tersebut (win-lose solution) (F. von BendaBeckmann, 1986). Sedangkan, model-model penyelesaian sengketa yang dikenal dalam masyarakat sederhana maupun kompleks (modern) pada pokoknya adalah:

1. Negosiasi, melalui proses kompromi antara pihak-pihak yangbersengketa, tanpa mengundang kehadiran pihak ketiga untuk menyelesaikan sengketa yang terjadi di antara mereka.

2. Mediasi, melalui kesepakatan antara pihak-pihak untuk melibatkanpihak ketiga (mediator) dalam penyelesaian sengketa, walau hanya berfungsi sebatas perantara (go-between) yang bersifat pasif, karena inisiatif untuk mengambil keputusan sebagai wujud penyelesaian sengketanya tetap didasarkan pada kesepakatan pihak-pihak yang bersengketa.

3. Arbitrasi, melalui kesepakatan untuk melibatkan pihak ketiga yangdisebut arbitrator sebagai wasit yang memberi keputusan dan keputusan tersebut harus ditaati dan dilaksanakan oleh pihak-pihak yang bersengketa.

4. Ajudikasi, sebagai model penyelesaian sengketa melalui institusipengadilan yang keputusannya mengikat pihak-pihak yang bersengketa (Roberts, 1978). Namun demikian, selain model-model penyelesaian sengketa seperti di atas, dalam masyarakat dikenal juga model-model penyelesaian sengketa seperti : 
1. Tindakan kekerasan (coersion), sebagai aksi yang bersifat unilateraldengan mengandalkan kekuatan fisik dan kekerasan, seperti melakukan tindakan hukum sendiri (self-hell) atau dalam bentuk perang antar suku (warfare).

2. Tindakan membiarkan saja (lumping it), yang dilakukan oleh salahsatu pihak dengan tidak menanggapi keluhan, gugatan, tuntutan pihak yang lain, atau mengabaikan sengketa yang teadi dengan pihak yang

lain.

3. Tindakan penghindaran (avoidance), yang dilakukan salah satupihak dengan menghindari sengketa dengan pihak lain, karena sejak awa! sengketa yang bersangkutan merasa secara sosial, ekonomi, politik, dan psikologis merasa sudah tidak berdaya untuk menghadapi pihak yang lain. Dengan demikian, tindakan menghindari sengketa dipandang paling aman dan menguntungkan tidak saja bagi diri sendiri, tetapi juga bagi keluarga dan kerabat, dalam rangka menjaga hubungan sosial yang bersifat jangka panjang (Nader \& Todd, 1978).

\section{Kesimpulan}

Model-model penyelesaian sengketa di atas sangat dipengaruhi oleh sistem nilai, keyakinan, norma, persepsi, dan sikap-sikap masyarakat dalam memaknai sengketa, dan dimensi-dimensi ini dalam perspektif antropologi hukum dikenal sebagai budaya hukum (legal culture) 
masyarakat dalam penyelesaian sengketa (Warasih, 1981). Pertanyaan yang muncul kemudian, bagaimanakah budaya hukum penyelesaian sengketa yang dianut masyarakat Indonesia? Dalam hubungan ini, Lev (1972) pernah melakukan penelitian mengenai budaya hukum penyelesaian sengketa dalam masyarakat Indonesia, khususnya masyarakat di daerah pedesaan Jawa dan Bali. Temuan penelitian tersebut pada pokoknya menyatakan seperti berikut:

1. Dalam kehidupan sosial sebagian besar masyarakat Indonesia cenderung untuk menghindari terjadinya sengketa dengan siapa pun, karena nilai-nilai pergaulan sosial yang dianut Iebih bersifat personal, komunal, mengutamakan solidaritas, dan bernuansa magis. Karena itu, apabila terjadi sengketa maka cenderung diselesaikan melalui prosedur kompromi, konsiliasi, mengutamakan pendekatan personal dan kekerabatan .

2. Sengketa antar individu sedapat mungkin dihindari, dan kalau punharus terjadi maka sengketa cenderung ditutupi dengan gaya hubungan sosial yang halus, untuk memperoleh penyelesaian yang tidak sampai merusak hubungan dan pergaulan sosial, apalagi menjatuhkan martabat atau merendahkan derajat pihak yang diajak bersengketa.

3. Fokus penyelesaian sengketa bukan pada penerapan peraturanhukum yang digunakan, tetapi Iebih pada upaya pelenyapan sengketa yang menjadi sumber ketegangan sosial.

4. Makna penyelesaian sengketa pada persoalan kalah-menang (win-lose solution), tetapi menjadi kewajiban bagi pihak-pihak untuk menghentikan sengketa dan meniadakan ketegangan sosial yang telah 
terjadi. Karena itu, yang diutamakan bukan penyelesaian substansi sengketanya, tetapi Iebih pada prosedur penyelesaian sengketanya. 5 . Pihak-pihak yang bersengketa Iebih melihat pihak ketiga (petugas hukum) yang dilibatkan untuk menyelesaikan sengketanya dan pada peraturanperaturan hukum yang mengatur penyelesaian sengketanya. Karena itu, petugas hukum ditaati masyarakat bukan karena alasan yang berkaitan dengan masalah kepatuhan masyarakat terhadap hukum.

\section{DAFTAR PUSTAKA}

[08.12, 24/1/2022] yogamusadi: Darmini Roza dan Laurensius Arliman S, Peran Pemerintah Daerah Di Dalam Melindungi Hak Anak Di Indonesia, Masalah-Masalah Hukum, Volume 47, Nomor 1, 2018. https://doi.org/10.14710/mmh.47.1.2018.10-21

Laurensius Arliman S, Peranan Metodologi Penelitian Hukum di Dalam Perkembangan Ilmu Hukum di Indonesia, Soumatera Law Review, Volume 1, Nomor 1, 201. http://doi.org/10.22216/soumlaw.v1i1.3346. Laurensius Arliman S, Peran Badan Permusyawaratan Desa di Dalam Pembangunan Desa dan Pengawasan Keuangan Desa, Padjadjaran Journal of Law, Volume 4, Nomor 3, 2017. https://doi.org/10.15408/jch.v4i2.3433.

Laurensius Arliman S, Penanaman Modal Asing Di Sumatera Barat Berdasarkan Undang- Undang Nomor 25 Tahun 2007 Tentang Penanaman Modal, Supremasi Hukum, Volume 1, Nomor 1, 2018. http://dx.doi.org/10.36441/hukum.v1i01.102 .

Laurensius Arliman S, Memperkuat Kearifan Lokal Untuk Menangkal Intoleransi Umat Beragama Di Indonesia, Ensiklopedia of Journal, Volume 1, Nomor 1, 2018, https://doi.org/10.33559/eoj.v1i1.18.

Laurensius Arliman S, Perkawinan Antar Negara Di Indonesia Berdasarkan Hukum Perdata Internasional, Kertha Patrika, Volume 39, Nomor 3, 2017, https://doi.org/10.24843/KP.2017.v39.i03.p03.

Laurensius Arliman S, Partisipasi Masyarakat Di Dalam Pengelolaan Uang Desa Pasca Undang-Undang Nomor 6 Tahun 2014 Tentang Desa, Jurnal Arena Hukum, Volume 12, Nomor 2, 2019, https://doi.org/10.21776/ub.arenahukum.2019.01202.5. 
Laurensius Arliman S, Mewujudkan Penegakan Hukum Yang Baik Di Negara Hukum Indonesia, Dialogica Jurnalica, Volume 11, Nomor 1, 2019, https://doi.org/10.28932/di.v11i1.1831.

Laurensius Arliman S, Mediasi Melalui Pendekatan Mufakat Sebagai Lembaga Alternatif Penyelesaian Sengketa Untuk Mendukung Pembangunan Ekonomi Nasional, UIR Law Review, Volume 2, Nomor 2, 2018, https://doi.org/10.25299/uirlrev.2018.vol2(02).1587

Laurensius Arliman S, Peranan Filsafat Hukum Dalam Perlindungan Hak Anak Yang Berkelanjutan Sebagai Bagian Dari Hak Asasi Manusia, Doctrinal, Volume 1, Nomor 2, 2016.

Laurensius Arliman S, Ni Putu Eka Dewi, Protection of Children and Womens Rights in Indonesia through International Regulation Ratification, Journal of Innovation, Creativity and Change Volume 15, Nomor 6, 2021.

Laurensius Arliman S, Gagalnya Perlindungan Anak Sebagai Salah Satu Bagian Dari Hak Asasi Manusia Oleh Orang Tua Ditinjau Dari Mazhab Utilitarianisme, Jurnal Yuridis, Volume 3, Nomor 2, 2016, http://dx.doi.org/10.35586/.v3i2.180.

Laurensius Arliman S, Tantangan Pendidikan Kewarganegaraan Pada Revolusi 4.0, Jurnal Ensiklopedia Sosial Review, Volume 2, Nomor 3, 2020. 